\title{
Shell utilization pattern of the hermit crab Clibanarius vittatus (Crustacea, Anomura) in an estuary at São Vicente, State of São Paulo, Brazil
}

\author{
Bruno S. Sant'Anna, Cilene M. Zangrande, Alvaro L. D. Reigada \& Marcelo A. A. Pinheiro \\ Universidade Estadual Paulista (UNESP), Campus do Litoral Paulista, Unidade São Vicente, Grupo de Pesquisa em Biologia de \\ Crustáceos (CRUSTA), Pça. Infante Dom Henrique, s/n, 11330-900 São Vicente, SP. (brunusant@ hotmail.com)

\begin{abstract}
We evaluated the gastropod shell utilization pattern of the hermit crab Clibanarius vittatus (Bosc, 1802) at Pescadores Beach in São Vicente, State of São Paulo, Brazil. Specimens were collected monthly from May 2001 through April 2003, in the intertidal zone at low tide. The crabs were weighed and their carapace shield length measured. All gastropod shells were identified and had their shell biometric parameters (total length and aperture length) measured (mm) and weighed (g). A total of 2,344 hermit crabs (644 males, 1,594 females, 45 ovigerous females and 61 individuals in intersex), using 13 species of gastropod shells, were collected. Stramonita haemastoma (Linnaeus, 1767), Cymatium parthenopeum (Von Salis, 1793) and Achatina fulica (Bowdich, 1822) comprised over $98 \%$ of all the shells. Male and intersex crabs were significantly larger than the females. This size difference strongly influenced the shell utilization pattern, principally in A. fulica, which has the largest shell size, that was only used by males and intersexual individuals of $C$. vittatus. Cymatium parthenopeum was the only shell species that showed a high determinant coefficient in all the biometric correlations evaluated. The high abundance of $S$. haemastoma shells and a strong correlation between crab size and shell aperture length established by a significant determination coefficient, indicated that $C$. vittatus uses this species as the principal resource for shell occupation at Pescadores Beach.
\end{abstract}

KEYWORDS. Hermit crab, shell, Anomura, Clibanarius, Gastropoda.

RESUMO. Padrão de utilização de conchas do ermitão Clibanarius vittatus (Crustacea, Anomura), no Estuário de São Vicente, Estado de São Paulo, Brasil. O objetivo do presente estudo foi avaliar a utilização de conchas de gastrópodes por Clibanarius vittatus (Bosc, 1802), na Praia dos Pescadores, em São Vicente (SP), Brasil. Foram realizadas amostras mensais no período de maio de 2001 a abril de 2003, na região intertidal durante a maré baixa. Todos os animais foram pesados e tiveram o comprimento de seu escudo cefalotorácico mensurados, suas conchas identificadas e medidas quanto ao comprimento ( $\mathrm{mm}$ ), abertura (mm) e peso (g). Capturamos 2.344 ermitões (644 machos, 1.594 fêmeas não-ovígeras, 45 fêmeas ovígeras e 61 em intersexo), utilizando 13 espécies de conchas de gastrópodes, das quais Stramonita haemastoma (Linnaeus, 1767), Cymatium parthenopeum (Von Salis, 1793) e Achatina fulica (Bowdich, 1822) representaram mais de $98 \%$ das conchas utilizadas. Obteve-se significativa diferença de tamanho entre os sexos, com machos e indivíduos em intersexo atingindo maior porte físico do que fêmeas. Este padrão influenciou fortemente na ocupação e utilização de conchas, principalmente em A. fulica, que foi a maior concha obtida por C. vittatus, utilizada somente por machos e indivíduos em intersexo. Cymatium parthenopeum foi a única espécie de concha em que se obtiveram elevados coeficientes de determinação para todas os parâmetros analisados. Stramonita haemastoma apresentou elevados e significativos coeficientes de determinação, indicando que esta espécie é o principal recurso de concha ocupada na Praia dos Pescadores.

PAlAVRAS-CHAVE. Ermitão, Concha, Anomura, Clibanarius, Gastropoda.

As for other hermit crab species, the wide geographical distribution of Clibanarius vittatus (Bosc, 1802) is explained by its high tolerance to unfavorable environmental conditions due to use of gastropod shells to protect its fragile abdomen (REESE, 1969). The shell used by a hermit crab can be either found empty, obtained by confrontations between individual crabs, or by removing the gastropod (Elwood \& NeIL, 1992). Many environmental factors influence the shell occupation pattern. The availability of shells is the most important parameter reported in previous studies (Orians \& KInG, 1964; NegreirosFransozo et al., 1991; Pinheiro et al., 1993; TuRRa \& LEITE, 2001), and is the main factor limiting populations of hermit crabs (Provenzano, 1960; Bollay, 1964; ReESe, 1969; HAZlett, 1970).

Hermit crabs usually have specific preferences for gastropod shell species (Reese, 1962; Orians \& King, 1964; Bertness, 1980). This preference is associated to shell architecture and size (CONOvER,
1978). Hermit crabs which occupy large shells can better resist to desiccation, thermal stress and predation (RitTsCHOF et al., 1995). A large gastropod shell has an ample internal area, which is favorable for somatic growth (HAzlett, 1981). However, heavy shells may limit reproduction and growth (BERTNESS, 1981; OsORNO et al., 1998), because of the high energy cost for locomotion. At the other hand, small shells render the crabs more vulnerable to predation and may reduce their growth rate (HAZLETT, 1981; ANGEL, 2000), since the crabs need larger shells for ecdysis throughout their ontogeny (Markham, 1968; Fotheringham, 1976a, b).

In spite of all these factors and also acquisition behavior and shell utilization, there is usually a strong correlation between the shell size and the size of the crab (ABRAMS, 1980; HAZLETT, 1981; ABRAMS et al., 1986). The purpose of the present study was to evaluate the pattern of gastropod shell use by $C$. vittatus, and to verify the most important biometric characters for shell selection. 


\section{MATERIAL AND METHODS}

Pescadores Beach (2358'21''S; 46²3'35'W), located in the estuarine channel of São Vicente, State of São Paulo, Brazil, harbors a diverse marine fauna, composed of molluscs, macroalgae and benthic crustaceans in the intertidal zone.

The hermit crabs were handly captured during low tide, from May 2001 to April 2003. Two people collected the crabs, monthly, for ten minutes; this time was established to standardize the capture effort throughout the period of study. Water salinity (\%o) was measured every month.

In the laboratory, the specimens were identified according to MeLo (1999), and the gastropod shells according to Rios (1994). The crabs with their gastropod shells were stored frozen until analysis. The crabs and shells were measured using a vernier caliper, to the nearest $0.01 \mathrm{~mm}$. The carapace shield length (CSL) was recorded from the tip of the rostrum to the midpoint of the cervical groove. The shell total length (SL) and aperture length (AL) were also measured. In the second year of the study, the hermit crab weight (HW) and their shell wet weight (WW) were determined in a precision balance $(0.01 \mathrm{~g})$; after oven-drying at $60^{\circ} \mathrm{C}$ for $24 \mathrm{~h}$, the shells were weighed again to record the dry weight (DW).

The shell utilization pattern in individual groups of C. vittatus (males, females, ovigerous females and intersexual specimens) was analyzed by the relative frequency in $1 \mathrm{~mm}$ size-classes (STURGES, 1926).

The shell variables SL, AL, WW and DW were considered dependent and were correlated with hermit crab morphometric variables (CSL and HW), taken as independent variables. The empirical points of these biometric relationships were submitted to regression analyses by the power function $\left(y=a x^{b}\right)$, with the best fit expressed by the determination coefficient $\left(\mathrm{r}^{2}\right)$.

The hermit crab shield length data were submitted to a Kruskal-Wallis test, a non-parametric method that is not dependent of the normal distribution, according to SoKal \& RoHlF (1995), at a 5\% significance level, to identify any possible difference in size between sexes.

\section{RESULTS}

A total of 2,344 hermit crabs were analyzed: 644 males, 1,594 females, 45 ovigerous females and 61 intersex individuals. The crabs occupied shells of 13 gastropod species: Stramonita haemastoma (Linnaeus, 1767), Cymatium parthenopeum (Von Salis, 1793), Achatina fulica (Bowdich, 1822), Dorsanum moniliferum (Valenciennes, 1834), Polinices hepaticus (Roding, 1798), Olivancillaria urceus (Roding, 1798), Buccinanops gradatum (Deshayes, 1844), Nassarius vibex (Say, 1822), Leucozonia nassa (Gmelin, 1791), Tegula viridula (Gmelin, 1791), Cerithium atratum (Born, 1778), Pisania pusio (Linnaeus, 1758) and Phalium granulatum (Born, 1778) (Tab. I).

Shells of S. haemastoma showed the highest percentage of occupation by crabs in all size classes, except in the first class $(2.5-3.5 \mathrm{~mm})$, probably due to the low number of individuals collected (Fig. 1). The gastropod shells had peculiar biometric characteristics (Tab. II), with similar weight and size in some species (e.g., C. parthenopeum and A. fulica). However, the aperture length was different, and was high in A. fulica, corresponding to the larger shell resource used by $C$. vittatus. Shells of this gastropod were only used by males and intersexual individuals, which were the largest specimens in this population (Fig. 2).

The figure 3 shows the regression analyses of biometric variables which correlate the shell aperture, length and weight to $C$. vittatus size and weight, respectively. The relationship of shell weight to hermit

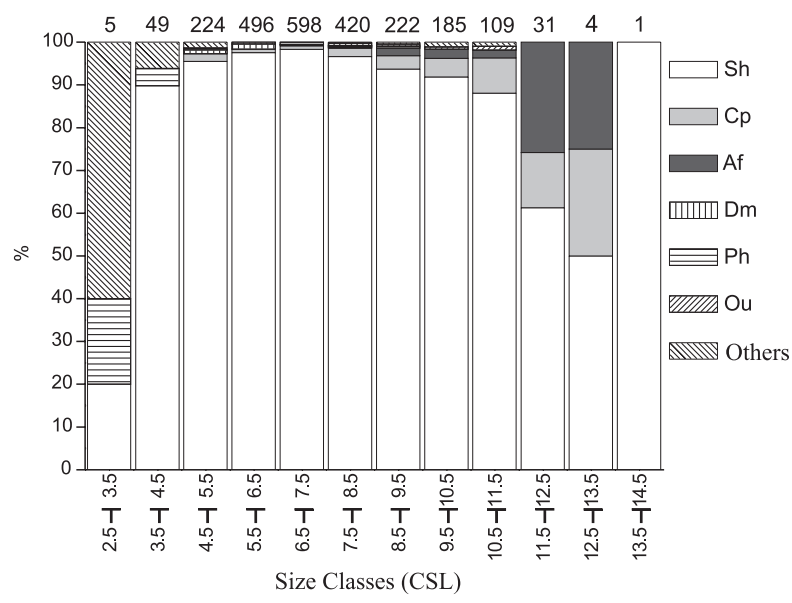

Fig. 1. Use of shells of different gastropod species by hermit crabs Clibanarius vittatus (Bosc, 1802) of different size classes (CSL, carapace shield length) (Af, Achatina fulica; Cp, Cymatium parthenopeum; Dm, Dorsanum moniliferum; Ou, Olivancillaria urceus; Ph, Polinices hepaticus; Sh, Stramonita haemastoma; Others, assemblage of Buccinanops gradatum, Cerithium atratum, Leucozonia nassa, Nassarius vibex, Phalium granulatum, Pisania pusio, Tegula viridula). The number at the top of the bars corresponds to the number of individuals in each size class.

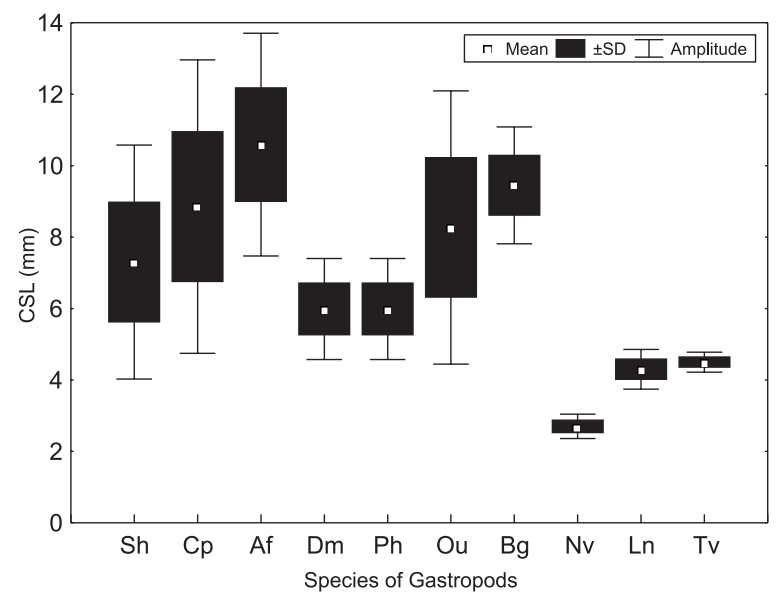

Fig. 2. Hermit crab size variation (CSL, carapace shield length) in the ten gastropod species with shells most commonly occupied by Clibanarius vittatus (Bosc, 1802) (Af, Achatina fulica; Bg, Buccinanops gradatum; Cp, Cymatium parthenopeum; Dm, Dorsanum moniliferum; Ln, Leucozonia nassa; Nv, Nassarius vibex; Ou, Olivancillaria urceus; Ph, Polinices hepaticus; Sh, Stramonita haemastoma; Tv, Tegula viridula). 

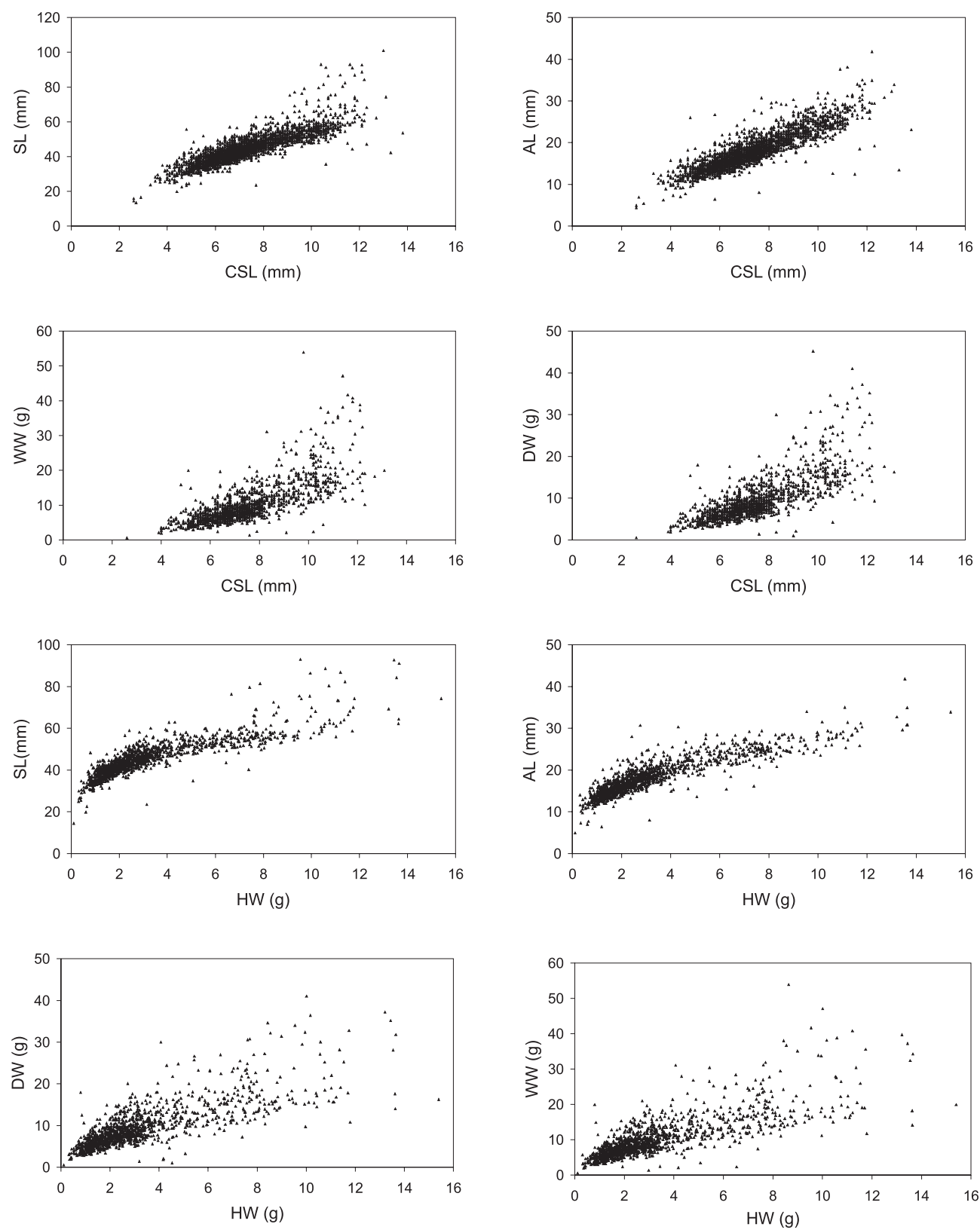

Fig. 3. Regression analyses between the biometric variables of gastropod shells utilized by Clibanarius vittatus (Bosc, 1802) (AL, aperture length; DW, dry weight; SL, total length and WW, wet weight) related to hermit crab sizes (CSL, carapace shield length and HW, weight).

Table I. Gastropod shell occupation by Clibanarius vittatus (Bosc, 1802) group (F, females; INT, individuals in intersex; M, males; N, number of individuals; OF, ovigerous females).

\begin{tabular}{|c|c|c|c|c|c|c|c|c|c|c|}
\hline \multirow{2}{*}{ Gastropod species } & \multicolumn{2}{|c|}{ M } & \multicolumn{2}{|c|}{$\mathrm{F}$} & \multicolumn{2}{|c|}{ OF } & \multicolumn{2}{|c|}{ INT } & \multicolumn{2}{|c|}{ TOTAL } \\
\hline & $\mathrm{N}$ & $\%$ & $\mathrm{~N}$ & $\%$ & $\mathrm{~N}$ & $\%$ & $\mathrm{~N}$ & $\%$ & $\mathrm{~N}$ & $\%$ \\
\hline Stramonita haemastoma & 582 & 24.83 & 1,552 & 66.21 & 44 & 1.88 & 55 & 2.35 & 2,233 & 95.26 \\
\hline Cymatium parthenopeum & 27 & 1.15 & 20 & 0.85 & & & 3 & 0.13 & 50 & 2.13 \\
\hline Achatina fulica & 19 & 0.81 & & & & & 2 & 0.08 & 21 & 0.89 \\
\hline Dorsanum moniliferum & 1 & 0.04 & 8 & 0.34 & 1 & 0.04 & & & 10 & 0.43 \\
\hline Polinices hepaticus & 3 & 0.13 & 6 & 0.26 & & & & & 9 & 0.38 \\
\hline Olivancillaria urceus & 6 & 0.26 & 1 & 0.04 & & & & & 7 & 0.30 \\
\hline Buccinanops gradatum & 3 & 0.13 & & & & & 1 & 0.04 & 4 & 0.17 \\
\hline Nassarius vibex & & & 3 & 0.13 & & & & & 3 & 0.13 \\
\hline Leucozonia nassa & & & 2 & 0.08 & & & & & 2 & 0.08 \\
\hline Tegula viridula & & & 2 & 0.08 & & & & & 2 & 0.08 \\
\hline Cerithium atratum & 1 & 0.04 & & & & & & & 1 & 0.05 \\
\hline Pisania pusio & 1 & 0.04 & & & & & & & 1 & 0.05 \\
\hline Phalium granulatum & 1 & 0.04 & & & & & & & 1 & 0.05 \\
\hline Total & 644 & 27.47 & 1,594 & 67.99 & 45 & 1.92 & 61 & 2.60 & 2,344 & 100 \\
\hline
\end{tabular}


crab biometric variables showed the lowest determination coefficient, except for $C$. parthenopeum, for which the coefficients were the highest - over $74 \%$ - of all the biometric relationships. In contrast, $A$. fulica coefficients were below $64 \%$ (Tab. III).

A significant hermit crab size difference was observed between sexes $(P<0.05)$, but there was no difference between males and intersexual individuals (Tab. IV).

The mean salinity throughout the period was $28.42 \pm 4.50 \%$. The monthly variation is shown in figure 4 .

Table II. Biometric variables of gastropod shells utilized by Clibanarius vittatus (Bosc, 1802). ( $\overline{\mathrm{x}} \pm$ sd, mean and standard deviation; AL, aperture length; DW, dry weight; N, number of shells measured; SL, total length; WW, wet weight).

\begin{tabular}{|c|c|c|c|c|c|c|}
\hline Species & $\mathrm{N}$ & $\mathrm{SL}(\mathrm{mm})$ & $\mathrm{AL}(\mathrm{mm})$ & $\mathrm{N}$ & WW(g) & $\mathrm{DW}(\mathrm{g})$ \\
\hline S. haemastoma & 2,233 & $44.5 \pm 7.7$ & $17.9 \pm 4.2$ & 1,174 & $9.9 \pm 5.5$ & $9.5 \pm 5.2$ \\
\hline C. parthenopeum & 50 & $65.2 \pm 17.6$ & $21.6 \pm 5.9$ & 25 & $18.8 \pm 10.3$ & $17.4 \pm 9.4$ \\
\hline A. fulica & 21 & $64.1 \pm 11.5$ & $29.9 \pm 4.7$ & 9 & $18.2 \pm 10.8$ & $15.6 \pm 8.4$ \\
\hline D. moniliferum & 10 & $39.2 \pm 2.7$ & $13.9 \pm 1.6$ & 4 & $4.5 \pm 0.7$ & $4.2 \pm 0.6$ \\
\hline P. hepaticus & 9 & $33.4 \pm 6.0$ & $18.7 \pm 3.9$ & 4 & $14.4 \pm 1.4$ & $13.8 \pm 4.4$ \\
\hline O. urceus & 7 & $45.9 \pm 4.8$ & $26.6 \pm 5.1$ & 2 & $17.9 \pm 12.1$ & $17.6 \pm 11.5$ \\
\hline B. gradatum & 4 & $54.8 \pm 2.8$ & $24.1 \pm 1.8$ & 3 & $9.7 \pm 2.0$ & $9.3 \pm 1.9$ \\
\hline N. vibex & 3 & $15.5 \pm 0.8$ & $4.9 \pm 0.5$ & 1 & 0.54 & 0.5 \\
\hline L. nassa & 2 & 29.4 & 8.3 & 1 & 3.29 & 3.2 \\
\hline T. viridula & 2 & 21.2 & 7.4 & 2 & 4.5 & 4.3 \\
\hline C. atratum & 1 & 34.9 & 8.9 & & & \\
\hline P. pusio & 1 & 33.1 & 10.6 & & & \\
\hline P. granulatum & 1 & 58.9 & 37.6 & & & \\
\hline Total & 2,344 & $44.9 \pm 8.9$ & $18.2 \pm 4.5$ & 1,225 & $10.2 \pm 5.9$ & $9.7 \pm 5.5$ \\
\hline
\end{tabular}

Table III. Linear regression analyses $(\operatorname{lny}=\ln a+$ blnx) between the independent variables $(x)$, carapace shield length (CSL) and the hermit crab weight (HW) of Clibanarius vittatus (Bosc, 1802) for the following shell biometric variables (y): aperture length (AL), dry weight (DW), total length (SL), wet weight (WW) (*, $P<0.05$; ns, not significant).

\begin{tabular}{|c|c|c|c|c|c|}
\hline Gastropod species & Relationship & $\mathrm{N}$ & Linear regression & $\mathrm{r}^{2}$ & $F$ \\
\hline \multirow{8}{*}{ S. haemastoma } & SL x CSL & 2,233 & $\ln \mathrm{SL}=2.45+0.675 \ln \mathrm{CSL}$ & 0.76 & $7,169.2 *$ \\
\hline & AL x CSL & 2,233 & $\ln \mathrm{AL}=1.14+0.873 \ln \mathrm{CSL}$ & 0.76 & $7,227.1 *$ \\
\hline & WW x CSL & 1,196 & $\ln \mathrm{WW}=-8.206+2.44 \ln \mathrm{CSL}$ & 0.53 & $1,387.9 *$ \\
\hline & DW x CSL & 1,174 & $\ln \mathrm{DW}=-1.23+1.69 \ln \mathrm{CSL}$ & 0.58 & $1,662 *$ \\
\hline & SL x HW & 1,196 & $\ln \mathrm{SL}=3.58+0.226 \ln \mathrm{HW}$ & 0.79 & $4,577.5 *$ \\
\hline & $\mathrm{AL} \times \mathrm{HW}$ & 1,196 & $\ln \mathrm{AL}=2.58+0.302 \ln \mathrm{HW}$ & 0.78 & $4,467.5 *$ \\
\hline & WW x HW & 1,196 & $\ln \mathrm{WW}=-1.19+1.704 \ln \mathrm{HW}$ & 0.58 & $1,706.8 *$ \\
\hline & DW x HW & 1,174 & $\ln \mathrm{DW}=1.57+0.587 \ln \mathrm{HW}$ & 0.62 & $1,938.4 *$ \\
\hline \multirow{8}{*}{ C. parthenopeum } & SL $x$ CSL & 50 & $\ln \mathrm{SL}=1.85+1.063 \ln \mathrm{CSL}$ & 0.87 & $343.4 *$ \\
\hline & $\mathrm{AL} \times \mathrm{CSL}$ & 50 & $\ln \mathrm{AL}=0.667+1.101 \ln \mathrm{CSL}$ & 0.91 & $543.5 *$ \\
\hline & WW x CSL & 26 & $\ln \mathrm{WW}=-2.43+2.35 \ln \mathrm{CSL}$ & 0.84 & $129.7 *$ \\
\hline & DW x CSL & 25 & $\ln \mathrm{DW}=-2.39+2.301 \ln \mathrm{CSL}$ & 0.83 & $119.6 *$ \\
\hline & SL x HW & 26 & $\ln \mathrm{SL}=3.58+0.339 \ln \mathrm{HW}$ & 0.88 & $181.8 *$ \\
\hline & AL x HW & 26 & $\ln \mathrm{AL}=2.49+0.351 \ln \mathrm{HW}$ & 0.91 & $255.2 *$ \\
\hline & WW x HW & 26 & $\ln \mathrm{WW}=1.69+0.1501 \ln \mathrm{HW}$ & 0.74 & $71.7 *$ \\
\hline & DW x HW & 25 & $\ln \mathrm{DW}=1.36+0.754 \ln \mathrm{HW}$ & 0.83 & $115.5 *$ \\
\hline \multirow{8}{*}{ A. fulica } & SL $x$ CSL & 21 & $\ln \mathrm{SL}=1.94+0.938 \ln \mathrm{CSL}$ & 0.63 & $32.4 *$ \\
\hline & AL x CSL & 21 & $\ln \mathrm{AL}=1.702+0.718 \ln \mathrm{CSL}$ & 0.52 & $20.8 *$ \\
\hline & WW x CSL & 9 & $\ln \mathrm{WW}=-5.63+3.44 \ln \mathrm{CSL}$ & 0.55 & $8.8 *$ \\
\hline & DW x CSL & 9 & $\ln \mathrm{DW}=5.58+3.36 \ln \mathrm{CSL}$ & 0.61 & $10.9 *$ \\
\hline & SL x HW & 9 & $\ln \mathrm{SL}=0.174+1.101 \ln \mathrm{HW}$ & 0.47 & $6.2 *$ \\
\hline & AL x HW & 9 & $\ln \mathrm{AL}=1.25+0.0828 \ln \mathrm{HW}$ & 0.55 & $8.6 *$ \\
\hline & WW x HW & 9 & $\ln \mathrm{WW}=2.75+1.41 \ln \mathrm{HW}$ & 0.19 & $1.6^{\mathrm{ns}}$ \\
\hline & DW x HW & 9 & $\ln \mathrm{DW}=1.34+0.116 \ln \mathrm{HW}$ & 0.46 & $6.0^{\mathrm{ns}}$ \\
\hline \multirow{8}{*}{ Total } & SL x CSL & 2,344 & $\ln \mathrm{SL}=2.37+0.719 \ln \mathrm{CSL}$ & 0.76 & $7,419.1 *$ \\
\hline & AL x CSL & 2,344 & $\ln \mathrm{AL}=1.087+0.90607 \ln \mathrm{CSL}$ & 0.77 & $8,033.3 *$ \\
\hline & WW x CSL & 1,250 & $\ln \mathrm{WW}=-1.26+1.73 \ln \mathrm{CSL}$ & 0.60 & $1,941.5 *$ \\
\hline & DW x CSL & 1,225 & $\ln \mathrm{DW}=-1.29+1.72 \ln \mathrm{CSL}$ & 0.60 & $1,874.4 *$ \\
\hline & SL x HW & 1,250 & $\ln \mathrm{SL}=2.56+0.245 \ln \mathrm{HW}$ & 0.79 & $4,232.3 *$ \\
\hline & $\mathrm{AL} \times \mathrm{HW}$ & 1,250 & $\ln \mathrm{AL}=2.58+0.309 \ln \mathrm{HW}$ & 0.80 & $4,999.6 *$ \\
\hline & WW x HW & 1,250 & $\ln \mathrm{WW}=1.62+0.598 \ln \mathrm{HW}$ & 0.64 & $2,292.3 *$ \\
\hline & DW x HW & 1,225 & $\ln \mathrm{DW}=1.57+0.5902 \ln \mathrm{HW}$ & 0.63 & $2,153.4 *$ \\
\hline
\end{tabular}


Table IV. Carapace shield length values of Clibanarius vittatus (Bosc, 1802) in mm (Max, maximum; Min, minimum; $\bar{x} \pm \mathrm{sd}$, mean and standard deviation) by group. Means followed by the same letter did not show a significant difference $(P>0.05)$.

\begin{tabular}{lrrrc}
\hline Sex & \multicolumn{1}{c}{$\mathrm{n}$} & Min & $\operatorname{Max}$ & $\overline{\mathrm{x}} \pm \mathrm{sd}$ \\
\hline Males & 644 & 2.7 & 13.8 & $9.2 \pm 1.8 \mathrm{a}$ \\
Females & 1,594 & 2.6 & 11.7 & $6.6 \pm 1.1 \mathrm{~b}$ \\
Ovigerous females & 45 & 4.9 & 9.4 & $6.6 \pm 1.1 \mathrm{~b}$ \\
Intersex & 61 & 5.4 & 12.3 & $9.5 \pm 1.4 \mathrm{a}$ \\
\hline Total & 2,344 & 2.6 & 13.8 & $7.1 \pm 1.7$ \\
\hline
\end{tabular}

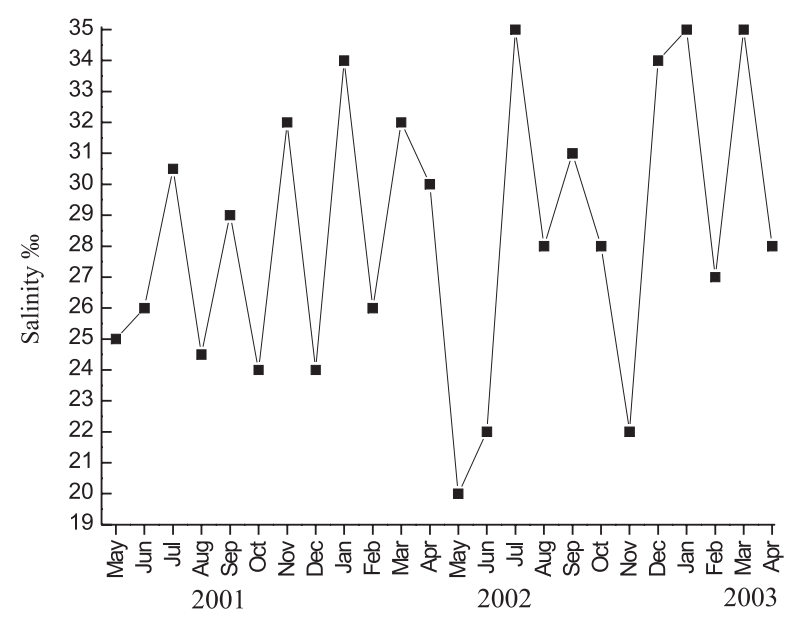

Fig. 4. Monthly mean values of water salinity during the sampling period at Pescadores Beach, São Vicente, State of São Paulo, Brazil.

\section{DISCUSSION}

Clibanarius vittatus is a common intertidal hermit crab of the Brazilian coast, and many studies have described aspects of its biology and ecology. At Pescadores Beach, C. vittatus occupied mostly shells of S. haemastoma, as previously observed by NegreirosFrANSOZO et al. (1991) in beaches of the São Sebastião and Reigada \& Santos (1997). A different shell occupation pattern was reported by TURRA \& LEITE (2002), with Chicoreus senegalensis (Gmelin, 1790) as the principal shell resource in Pernambuco Inlet, São Sebastião. However, TuRRA \& LeITE (2002) also observed a preference for $S$. haemastoma in laboratory experiments. This confirms that $C$. vittatus has a specific preference in shell occupation, which may vary according to local occurrence and geographical distribution (NEGREIROsFRANSOZO et al., 1991).

Despite the high occupation frequency of $S$. haemastoma, the highest determination coefficient was found for $C$. parthenopeum; the shell of $C$. parthenopeum differs morphologically from that of $S$. haemastoma: it is more robust and provides better protection for the crabs.

LOWERy \& Nelson (1988) and Reigada \& Santos (1997) observed that males of $C$. vittatus grow much larger than females. The same pattern was seen in the present study, i.e., the size difference between sexes and the shell occupation of A. fulica by males and specimens in intersex.
NAKASONE (2001) recorded an inverse pattern for two species of terrestrial hermit crab, Coenobita cavipes Stimpson, 1858 and C. purpureus Stimpson, 1858, with large females using A. fulica shells in Okinawa, Japan. This land snail shell is large but lightweight (OsORNo et al., 1998). Use of A. fulica shells may reduce the energetic cost of carrying the shell (HeRREID \& Full, 1986). The occupation of $A$. fulica shells by males of $C$. vittatus could be explained by the small number of large shells available at Pescadores Beach, including shells of $A$. fulica and $C$. parthenopeum. According to RitTsCHOF et al. (1995), large shells have ample internal space, which may provide several advantages for the crabs, such as high somatic growth, resistance to desiccation and thermal stress, and low risk of predation. At Pescadores Beach, the use of A. fulica shells by $C$. vittatus could be explained by the common presence of this gastropod in suprallitoral vegetation that they were eating. This zone is regularly wetted by seawater during high tide, which occasionally killed these gastropods and guaranteed a supply of empty shells for $C$. vittatus.

TURRa \& LeIte (2002) established correlations between the shell weight and the size of $C$. vittatus (DW $\mathrm{x}$ CSL), using a single log-linear equation, and found a low determination coefficient $\left(\mathrm{r}^{2}=0.28\right)$. In the present study, the coefficient calculated for the same relationship was three times higher $\left(r^{2}=0.60\right)$ than the value found by TURRA \& Leite (2002), but it was lower than the obtained for relationships which involve size $\left(r^{2}=0.76\right)$ or shell aperture $\left(\mathrm{r}^{2}=0.77\right)$. All the coefficients of $C$. parthenopeum calculated by regression analyses were higher than 0.74. A congener, Clibanarius erythopus (Latreille, 1818), studied by Botelho \& Costa (2000), showed a low correlation in DW x CSL relationship in most of the shells analyzed. This could be explained by shells damage, in almost situation, caused by the presence of encrusting organisms which influence negatively in the hermit crabs reproduction, growth and locomotion (BerTness, 1981; Osorno et al., 1998; SANT'AnNa et al., 2004). Encrusting organisms were found on all shell surfaces (external and internal) analyzed at Pescadores Beach, but the presence of these organisms did not perceptibly limit hermit crab occupation. Stramonita haemastoma was apparently a good shell resource, because it showed a high determination coefficient even in the presence of encrusting organisms.

Stramonita haemastoma was the most abundant intertidal gastropod species at Pescadores Beach and adjacent areas (B. S. Sant'Anna, personal observation). Shells of this species showed good biometric correlation (shell aperture and total length) with hermit crab size. These morphological characters act in synergy to determine the shell utilization pattern in this estuary, where in many cases, the most abundant gastropod species is not the one most used by hermit crabs (Borjesson \& Szelistowski, 1989; TuRRA \& LeITe, 2001). At Pescadores Beach, many living individuals and empty shells of the small gastropods Nassarius vibex and Littorina flava King \& Broderip, 1832 were present. Few crabs occupied shells of the former species, and no crabs occupied the latter. The lower rate of use of these small shells was a consequence of the absence of $C$. vittatus 
juveniles in the region, probably because of the strong influence of continental waters, which cause wide variations in salinity in this area. The lower-salinity water is not tolerated by $C$. vittatus larvae, especially in the last metamorphosis (transition megalopae and juvenile individuals), as reported by Young \& HAzLETT (1978).

Acknowledgements. We are grateful to Biologist Carlo Magenta Cunha for identifying this species of gastropod, to MSc. Gustavo Y. Hattori for translating the manuscript into English and the Dra ${ }^{\mathrm{a}}$. Janet W. Reid checked the English text of the final version. We also thank the referee, for valuable recommendations.

\section{REFERENCES}

Abrams, P. A. 1980. Resource partitioning and interspecific competition in a tropical hermit crab community. Oecologia 46:365-379.

Abrams, P. A.; Nyblade, C. \& Sheldon, S. 1986. Resource partitioning and competition for shells in a subtidal hermit crab species assemblage. Oecologia 69:429-445.

Angel, J. E. 2000. Effects of shell fit in the biology of the hermit crab Pagurus longicarpus (Say). Journal of Experimental Marine Biology and Ecology 243(2):169-184.

Bertness, M. D. 1980. Shell preference and utilization patterns in littoral hermit crabs of the Bay of the Panamá. Journal of Experimental Marine Biology and Ecology 48:1-16. 1981. The influence of shell type on hermit crab growth rate and clutch size (Decapoda, Anomura). Crustaceana 40: 197-205.

Bollay, M. 1964. Distribution and utilization of gastropod shells by the hermit crabs Pagurus samuelis, $P$. granosimanus and $P$. hirsutiusculus at Pacific Grouve, California. Veliger (supl.) 6:71-75.

Borjesson, D. L. \& Szelistowski, W. A. 1989. Shell selection, utilization and predation in the hermit crab Clibanarius panamensis Stimpson in a tropical mangrove estuary. Journal Experimental of the Marine Biology and Ecology 133:213-228.

Botelho, A. Z. \& Costa, A. C. 2000. Shell occupancy of the intertidal hermit crab Clibanarius erythropus (Decapoda, Diogenidae) on São Miguel (Azores). Hydrobiologia 440:111117 .

Conover, M. 1978. Importance of various shell characteristics to the shell selection behavior of the hermit crabs. Journal of Experimental Marine Biology and Ecology 32:131-142.

Elwood, R. W. \& Neil, S. J. 1992. Assesments and Decisions. London, Chapman \& Hall. 192p.

Fotheringham, N. 1976a. Hermit crab shells as a limiting resource (Decapoda: Paguridae). Crustaceana 31(2):193-199.

_. 1976b. Population consequences of shell utilization by hermit crabs. Ecology 57:570-578.

Hazlett, B. A. 1970. Interspecific shell fighting in three sympatric species of the hermit crabs in Hawaii. Pacific Science 24:472-482. 1981. The behavioral ecology of the hermit crab. Annual Review of Ecology and Systematics 12:1-22.

Herreid, C. F. \& Full, R. J. 1986. Energetics of hermit crabs during locomotion: the cost of carrying a shell. Journal of Experimental Biology 120:297-308.

Lowery, W. A. \& Nelson, W. G. 1988. Population ecology of the hermit crab Clibanarius vittatus (Decapoda: Diogenidae) at
Sebastian Inlet, Florida. Journal of Crustacean Biology 8(4):548-556.

Markham, J. C. 1968. Notes on growth patterns and shell utilization of the hermit crab Pagurus bernhardus (L.). Ophelia 5:189-205.

Melo, G. A. S. 1999. Manual de identificação dos Crustacea Decapoda do litoral brasileiro: Anomura, Thalassinidea, Palinuridea, Astacidea. São Paulo, Plêiade. 551p.

NAKASONE, Y. 2001. Reproductive biology of the three land hermit crabs (Decapoda: Anomura: Coenobitidae) in Okinawa. Japan Pacific Science 55(2):157-169.

Negreiros-Fransozo, M. L.; Fransozo, A. \& Hebling, N. J. 1991. Estrutura populacional e determinação do tamanho da concha ocupada por quatro espécies de ermitões (Crustacea, Decapoda, Anomura) do litoral de São Paulo. Biotemas 4(2):135-148.

Orians, G. H. \& KING, C. E. 1964. Shell selection and invasion rates of some pacific hermits crabs. Pacific Science 18:297-306.

Osorno, J. L.; Fernandez-Casillas, L. \& Rodriguez-Juarez, C. 1998. Are hermit crabs looking for light and large shell? Evidence from natural and field induced shell exchanges. Journal of Experimental Marine Biology and Ecology 222(1): 163-173.

Pinheiro, M. A. A.; Fransozo, A. \& Negreiros-Fransozo, M. L. 1993. Seleção e relação com a concha em Isocheles sawayai Forest \& Saint Laurent, 1967 (Crustacea, Anomura, Diogenidae). Arquivos de Biologia e Tecnologia do Paraná 36(4):745-752.

Provenzano, A. J. J. R. 1960. Notes on the Bermuda hermit crabs (Crustacea: Anomura). Bulletin of Marine Science of the Gulf and Caribbean 10:117-124.

REESE, E. S. 1962. Shell selection behavior of the hermit crabs. Animal Behavior 10:347-360.

1969. Behavioral adaptations of intertidal hermit crabs American Zoology 9:343-355.

ReigadA, A. L. D. \& SAntos, S. 1997. Biologia e relação com a concha em Clibanarius vittatus (Bosc, 1802) (Crustacea, Diogenidae) em São Vicente, SP, Brasil. Arquivos de Biologia e Tecnologia do Paraná 40(4):941-952.

Rios, E. 1994. Sea shells of Brazil. Rio Grande, Furg. 368p.

Rittschof, D.; Sarrica, J. \& Rubenstein, D. 1995. Shell dynamics and microhabitat selection by striped legged hermit crabs, Clibanarius vittatus (Bosc). Journal of Experimental Marine Biology and Ecology 192(2):157-172.

Sant' Anna, B. S.; Zangrande, C. M.; Costa, T. M. \& Reigada, A. L. D. 2004. Simbiose em conchas do ermitão Clibanarius vittatus (Bosc, 1802) (Crustacea, Decapoda, Anomura). In: Congresso Brasileiro de Pesquisas Ambientais e da Saúde, 4º Santos, 2004. Anais... v.1, p.231-234. CD-ROM

Sokal, R. R. \& Rohlf, F. J. 1995. Biometry. New York, W.H. Freeman and Company. $887 \mathrm{p}$.

Sturges, H. A. 1926. The choice of a class interval. Journal of American Statistical Associations 21:65-66.

Turra, A. \& Leite, F. P. P. 2001. Shell utilization of a tropical rocky intertidal hermit crab assemblage: I. The case of Grande Beach. Journal of Crustacean Biolology 21(2):393-406.

. 2002. Shell utilization patterns of a tropical intertidal hermit crab assemblage. Journal of the Marine Biology Association U.K. 82:97-107.

Young, A. M. \& Hazlett, T. L. 1978. The effect of salinity and temperature on the larval development of Clibanarius vittatus (Bosc) (Crustacea: Decapoda: Diogenidae). Journal of Experimental Marine Biology and Ecology 34:131-141. 